\title{
Hemocyte characteristics in families of oysters, Crassostrea gigas, selected for differential survival during summer and reared in three sites
}

\author{
Christophe Lambert ${ }^{1}$, Philippe Soudant ${ }^{1^{*}}$, Lionel Dégremont ${ }^{2}$, Maryse Delaporte ${ }^{3}$, Jeanne \\ Moal $^{3}$, Pierre Boudry ${ }^{2}$, Fredéric Jean ${ }^{1}$, Arnaud Huvet ${ }^{3}$, and Jean-François Samain ${ }^{3}$.
}

1 : Laboratoire des Sciences de l'Environnement Marin, Institut Universitaire Européen de la Mer, Université de Bretagne Occidentale. Place Copernic, Technopôle Brest-Iroise. 29280 Plouzané, FRANCE.

2 : Laboratoire de Génétique et Pathologie (LGP) IFremer, Ronce-Les-Bains, 17390 La Tremblade, France.

3 : Laboratoire de Physiologie des Invertébrés Marins (LPI) IFremer, centre de Brest, B.P. 70, 29280 Plouzané, France.

* Author for correspondence: P. Soudant, Phone: +33 2984986 23, Fax.: +33 2984986 45, E-mail: Philippe.Soudant@univ-brest.fr

\begin{abstract}
:
High variability among individuals is often encountered when hemocyte characteristics are measured in bivalves. Such variability is suspected to result partly from genetic factors. In this study, hemocyte characteristics of six families of Crassostrea gigas were compared by flow cytometry at one sampling date in October 2001. These families were obtained from a nested, half-sibling cross design, and reared from July to October 2001 at three sites distributed along the French Atlantic coast from north to south: Baie des Veys (Normandy), Rivière d'Auray (Brittany) and Ronce (Marennes-oléron Basin, Poitou Charentes).

Among the 15 measured hemocyte characteristics, production of reactive oxygen species-(ROS) of untreated hemocytes (maintained in filtered sterile seawater) and treated hemocytes (zymosan at 20 particles per hemocyte, and with Vibrio sp. S322 at 50 bacteria per hemocytes) was the most notably different between families. This supports the existence of a genetic basis, at least partly, for the hemocyte characteristics of oysters, and especially for ROS production.

Among the six families analyzed, three have shown high survival during summer (named as "resistant", mean mortality $5.2 \%$ ) and three experienced high mortality during summer (named as "susceptible", $30.6 \%$ mean mortality). Families showing high or low survival to summer mortality had similar hemocyte characteristics, regardless of the environmental conditions or reproductive state. Resistant families were observed to have higher total hemocyte counts and lower production of ROS than susceptible families. Moreover, ROS production of hemocytes from susceptible families was diminished significantly more by pathogenic Vibrio than that of resistant families. However, this study demonstrates also that rearing site strongly affected the hemocyte characteristics of all families of oysters, most notably hemocyte concentration and morphology (size and granularity), production of reactive oxygen species (ROS), and susceptibility to the cytotoxic activity of the pathogenic Vibrio sp. S322 (50 bacteria/ hemocyte). Food availability and reproductive state are the most probable explanations for the site differences observed. Finally, it appeared difficult to link oyster survival during summer mortality to hemocyte profiles evaluated at one sampling date; other relevant indicators would probably help explaining oyster survival during summer mortality events.
\end{abstract}

Keywords: Summer mortality; Crassostrea gigas; Hemocyte; Adhesion; Reactive oxygen species (ROS); Flow cytometry; Genetic 


\section{Introduction}

Summer mortalities have been reported in the Pacific oyster, Crassostrea gigas, for many years and in several countries (Glude, 1974; Koganezawa, 1974; Cheney et al., 2000). In France, summer mortality affects both adults and juveniles (Goulletquer et al., 1998), with no clinical signs of diseases. A combination of environmental, physiological and pathological (Waechter et al., 2002) factors were proposed as possible causes of oyster summer mortality. Oysters have died mainly during the reproductive period when water temperatures are over a critical value of $19^{\circ} \mathrm{C}$ (Soletchnik et al., 1999; Soletchnik et al., 2003; Soletchnik et al., 2005). The high energetic cost associated with reproduction, combined with high summer temperatures, is suspected to weaken the oysters and make them more susceptible to opportunistic pathogens.

It is well-established that the capability of an oyster to react to diseases, injuries or parasite infestation depends upon the innate-immune defense system (Hégaret et al., 2003a). Hemocytes are considered to be the main cellular mediators of the defense system in bivalves (Volety, Chu, 1995; Cheng, 1996). Ability to quantify morphological and functional characteristics of oyster hemocytes has been improved recently by advanced methods of single-cell analysis by flow-cytometry. In 1994, cytometric analyses of oyster hemocytes were initiated (Ford et al., 1994). More recently, flow-cytometric methods were adapted to analyze C. gigas hemocytes (Lambert et al., 2003), specifically, total and differential counts of different types of hemocytes and production of reactive oxygen species (ROS). Methods were successfully used in C. gigas and Ruditapes philippinarum hemocytes (Delaporte et al., 2003) to study

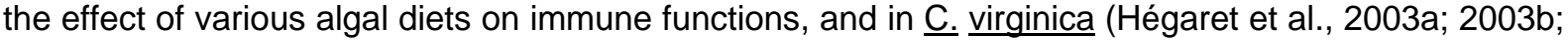
Hégaret et al., 2004) to study the effect of a sudden temperature elevation, as well as quantity and quality of algal diet, on hemocyte characteristics. In the present study, hemocyte measurements made were: total and differential hemocyte counts, morphology of the cell sub populations (size and granularity), production of reactive oxygen species (ROS), adhesion, and susceptibility of oyster hemocytes to a pathogenic Vibrio. Functionnal parameters such as ROS production or adhesion can provide information concerning defense capacity of the hemocytes as well as environmental condition (stress). Descriptive parameters, such as hemocyte concentration or size could provide information on cell division or infection processes. Increase in granularity could reveal the synthesis of enzymes within granules in the hemocyte cytoplasm. However, interpretation of these hemocyte variables remains tentative because they have been applied in few studies in bivalves.

As noted above, opportunistic pathogens were suspected to act as a final, lethal stress in oysters previously weakened by gonad maturation and high temperature. As the possible role of opportunistic pathogens in oyster summer mortality was hypothesized, the susceptibility of hemocyte functions to an opportunistic Vibrio sp. was assessed.

Genetic variability is suspected to influence bivalve defense capabilities. Indeed, It has been shown that susceptibility to summer mortality can be linked, to some extent, to genetic heritage (Beattie et al., 1980; Hershberger et al., 1984; Ernande et al., 2004; Degremont et al., 2007). To better understand the influences of genetic history on oyster summer mortalities, a national, multidisciplinary program (the MOREST project) was established in France. The program developed a genetic selection approach to assess whether selective breeding could modulate survival under varying environmental conditions (Dégremont, 2003; Dégremont et al., 2003; Dégremont et al., 2005; Degremont et al., 2007).

Thus, in the present study, oysters from six bi-parental families were reared at three different experimental sites along the French coast during summer (from July to October). Then, their hemocyte characteristics - morphological and functional - were compared once in October 2001, at least one month after the "normal" spawning period (July - August in the southern sites and August-September for the northern site). These six families were composed of three families presenting low survival, named "susceptible" and three with high survival during summer, named "resistant" Comparisons were analyzed to answer two main questions: 1) Do oyster hemocyte characteristics have a genetic basis, independent of environmental conditions? 2) Does the selection based upon summer survival lead to different hemocyte characteristics? 


\section{Material and methods}

\subsection{Production and selection of families}

Production and selection of families have been previously described in detail (Dégremont et al., 2005;

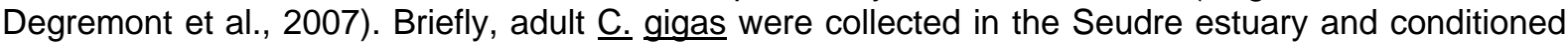
in the IFremer hatchery at La Tremblade (Poitou-Charentes, France, Fig. 1) to form the parental population. In March 2001, bi-parental families were produced by crossing each of six males with different females. Each family is noted as follows: letter $F$ for family then the number of the male, hyphen, the number of the female (example: F9-34). After larval and post-larval culture at La Tremblade according to methods previously described (Ernande et al., 2003), progeny from 15 families were tested in the field. In July 2001, at age 4-months, these 15 families were deployed at three sites along the French coast (Fig. 1): Ronce (southwest), Rivière d'Auray (west) and Baie des Veys (northwest). The sites represented various environmental conditions for oyster culture along the French coast, with differing temperature cycles, food availability, etc. Oysters were reared following usual practices on $70 \mathrm{~cm}$-high racks, in $7 \mathrm{~mm}$-mesh, flat plastic bags.

Survival and growth were assessed after 89 days of rearing in October 2001 (Dégremont et al., 2005). From the 15 families, six were then selected according to their survival and used for hemocyte sampling: three susceptible families showing low survival, and three resistant families showing high survival. Reproductive state was estimated visually by using a basic gonadic maturation scale (P.G. Fleury, Ifremer, personal communication) and confirmed by neutral lipids analysis (J. Moal and JR Le Coz, Ifremer, unpubl. data).

\subsection{Sampling of oysters for hemocyte measurements}

In October 2001, after approximately three months deployment on-site, 20 animals from each of the 6 selected families, from each of the three sites, were transported in coolers maintained at $4^{\circ} \mathrm{C}$ to the laboratory at the IUEM (Institut Universitaire Européen de la Mer, Brittany). Animals from the first site were received on day one, those from the second site on day two and those of the third site on day three. Particular care was taken to apply identical conditions to oysters from all sites.

After arrival, a notch was ground in the oyster shell to facilitate hemolymph extraction, and animals were left for about 24 hours in a flow-through seawater system at $15-16^{\circ} \mathrm{C}$ and $34-35$ salinity. These conditions are very close to those found in October in the three study sites. In fact, data collected from 2000 to 2005 (M. Ropert, IFremer Port en Bessin, France, personal communication.) showed that the mean seawater temperature in October was approximately $16^{\circ} \mathrm{C}\left(15.5\right.$ to $\left.16.5^{\circ} \mathrm{C}\right)$ and that differences between the three sites during this period of the year were less than $0.5^{\circ} \mathrm{C}$.

\subsection{Vibrio suspension preparation}

One Vibrio sp. culture, strain S322, was used in this study. The strain is pathogenic to larvae of the scallop Pecten maximus and to the oysters $\underline{C}$. gigas and Ostrea edulis (Nicolas et al., 1996) and has been shown to reduce the ROS production of $\underline{P}$. maximus and $\underline{C}$. gigas hemocytes (Lambert, Nicolas, 1998; Lambert et al., 2001; Lambert et al., 2003). The strain was cultured in Zobell's 2216E medium (Difco) at $18^{\circ} \mathrm{C}$ on a shaker table for 24 hours. Cultured bacterial cells were collected by centrifugation $(2,500 \mathrm{~g}, 10 \mathrm{~min})$, washed twice with sterile-filtered seawater (FSSW), and re-suspended in FSSW. Bacterial-cell density was measured as optical density (O.D.) at $492 \mathrm{~nm}$, at which the correlation between direct counts (colony forming units) and O.D. had been previously established.

\subsection{Hemolymph sampling}

Sampling and analysis of all 6 selected families from each site were performed within one day. Hemolymph was withdrawn from the adductor muscle, through the notch previously ground, using a 1$\mathrm{ml}$ plastic syringe fitted with a 25-gauge needle. Bleeding of 120 oysters was achieved within 2 hours, thus all families were sampled synoptically. Hemolymph from each oyster was transferred into an individual micro-centrifuge tube held on ice to minimize cell clumping prior to analysis. Hemolymph from at least 5 animals was pooled and then filtered through a 80- $\mu \mathrm{m}$ mesh. For each family, three pools of 5 individuals were made, for a total of 18 pools from the six families for each site.

Pooling of hemolymph was chosen instead of individual measurement for practical reasons. In fact, oysters sampled were only 7 months old, with a mean weight of about $12 \mathrm{~g}$ and a shell height of approximately $5 \mathrm{~cm}$. Withdrawing the $900 \mu \mathrm{L}$ volume of hemolymph needed to complete all assays 
was thus impossible from such small individuals. The use of pooled samples of hemolymph was previously validated to evaluate the mean and variance of hemocyte measurements for the oyster $\underline{\mathrm{C}}$. virginica (Hégaret et al., 2003b).

\subsection{Measurements of hemocyte parameters by flow cytometry}

Quantification of hemocyte type, number and functions were determined using a FACScalibur (BD Biosciences, San Jose, CA USA) flow-cytometer equipped with a $488 \mathrm{~nm}$ argon laser. Methods to measure hemocyte parameters are described hereafter.

\subsubsection{Total and differential hemocyte counts}

Total and differential hemocyte counts were measured according to described methods (Delaporte et al., 2006). A 100- $\mu$ sub-sample from each hemolymph pool was fixed by adding $300 \mu \mathrm{l}$ of a $4 \%$ formalin solution in FSSW. Samples were incubated with SYBR ${ }^{\circledR}$ green I (Molecular Probes, 10X final concentration, $=1 / 1000$ of the DMSO commercial solution), a nucleic acid-specific dye, in darkness at room temperature for 30 minutes before flow-cytometric analysis. For each particle, the flow cytometer measured side scatter (SSC), representing granularity or internal complexity of particles, forward scatter (FSC), estimating the size of particles, and fluorescence intensity with the FL1 detector (yellow fluorescence) to detect the SYBR ${ }^{\circledR}$ green-stained particles. A density plot visualization, in log scale, of SSC vs FL1 allowed differentiation and gating of hemocytes stained by SYBR ${ }^{\circledR}$ green from other particles in the hemolymph. Three distinct sup-populations of hemocytes (Fig. 2) were identified on a FSC-SSC density plot according to their SSC and FSC ranges; these were termed: granulocytes (high SSC and high FSC) hyalinocytes (low SSC, high FSC) and small agranulocytes (low FSC and low SSC). The flow rate of the cytometer was measured as previously described (Marie et al., 1999) by weighing a tube containing distilled water before and after a timed analysis to determine the volume analyzed. Calculated flow rate was used to determine hemocyte concentrations. For suspended cell concentrations, results were expressed as total hemocytes, granulocytes, hyalinocytes and small agranulocytes per ml; for morphological characteristics, results were expressed as FSC and SSC values, in arbitrary units recorded by the cytometer, for size and the granularity, respectively, of the three hemocyte sub-populations.

\subsubsection{Reactive oxygen species (ROS) production}

Measurement of ROS production was done using 2'7'-dichlorofluorescin diacetate (DCFH-DA, Sigma). The method used was first described in mammalian blood cells (Bass et al., 1983) and recently adapted to C. gigas hemocytes (Lambert et al., 2003) and to C. virginica (Hégaret et al., 2003a; 2003b; Goedken, De Guise, 2004). One advantage of this flow-cytometric method is the ability to differentiate ROS production in different hemocyte sub-populations, even during or after phagocytosis of non self particles such as zymosan or bacteria (Hégaret et al., 2003a; Lambert et al., 2003).

To prepare the zymosan-particle working suspension used in this work, $200 \mathrm{mg}$ of zymosan A (Sigma) were suspended in $10 \mathrm{ml}$ of FSSW, heated in a boiling-water bath for 30 minutes, and then washed twice and re-suspended in FSSW. Particle count was done microscopically using a Malassez cell, and aliquots were frozen at $-20^{\circ} \mathrm{C}$.

For the ROS-production assay, hemocyte concentrations of the 18 different hemolymph pools were equalized by adding FSSW. Next, three sub-samples of $200 \mu \mathrm{l}$ hemolymph from each of the 18 pools were distributed into 5-ml polystyrene tubes (Falcon $\left.{ }^{\circledR}\right)$ and maintained on ice. Zymosan particles were added to one sub-sample $(300 \mu \mathrm{l})$ to a final ratio of 20 particles per hemocyte. Vibrio sp. strain S322 was added $(300 \mu \mathrm{l})$ to a second sub-sample at a final ratio of 50 bacteria per hemocyte. Finally, $300 \mu \mathrm{l}$ of FSSW were added to the third sub-sample as a control (untreated hemocytes).

Four $\mu \mathrm{L}$ of a DCFH-DA working solution (1mM in 10\% DMSO FSSW) were added to each tube to yield a final concentration of $0.01 \mathrm{mM}$. Measurements were performed after 120 min of incubation at room temperature $\left(20-22^{\circ} \mathrm{C}\right)$ for the zymosan assay and after 180 minutes for untreated hemocytes (+FSSW) and the Vibrio assay. The duration of each measurement was 30 seconds. Incubation time was chosen according to previous results (Lambert et al., 2003) showing that ROS production in untreated hemocytes reached a plateau at $180 \mathrm{~min}$; For the Vibrio assay, an effect of live bacteria was noted only from $t=180$ min but an effect of addition of zymosan particles was noted within 2 hours.

For each sub-population, the DCF green fluorescence intensity measured at $500-530 \mathrm{~nm}$ by the FL1 detector of the flow cytometer was expressed in arbitrary detector units. Intracellular oxidation of $\mathrm{DCFH}$ to fluorescent DCF is quantitatively related to hemocyte ROS production. 
Results were expressed as:

- The mean fluorescence (FL1 in arbitrary units) of the different hemocyte sub-populations in FSSW at $\mathrm{t}=180 \mathrm{~min}$.

- The ratio of the FL1 fluorescence of the different hemocyte sub-populations incubated with zymosan particles to fluorescence in FSSW at $\mathrm{t}=120 \mathrm{~min}$. This ratio represented the activation of hemocyte ROS production by the zymosan particles.

- The ratio of the FL1 fluorescence of the different hemocyte sub-populations incubated with Vibrio sp. S322 to fluorescence in FSSW at $t=180$ min. A ratio near 1 indicated that the hemocyte ROS production was not modified by the addition of bacteria; a ratio less than 1 corresponded to inhibition of the hemocyte ROS production; a ratio greater than 1 indicated activation (Lambert et al., 2003).

\subsubsection{Hemocyte adhesion}

Hemocytes are naturally able to adhere to a glass or plastic surface, usually within 30 min at room temperature (Bachère et al., 1991; Lambert, Nicolas, 1998). Interestingly, some Vibrio species are known to inhibit hemocyte adhesion (Choquet et al., 2003). In this study, the method utilized to assess hemocyte susceptibility to pathogenic bacteria was adapted from a previous study (Choquet et al., 2003), but using the Vibrio sp. strain S322 (see § "Vibrio suspension preparation"). In this cytotoxicity assay, contact between hemocytes and bacteria was accomplished in 24-well micro-culture plates.

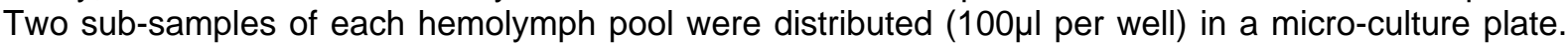
Then, $100 \mu \mathrm{l}$ of FSSW were added to the first sub-sample as a control and $100 \mu \mathrm{l}$ of Vibrio sp. (S322) suspension to the second, to obtain a final ratio of 50 bacteria per hemocyte. After three hours of incubation at $18^{\circ} \mathrm{C}, 200 \mu \mathrm{l}$ of a $6 \%$ formalin solution in FSSW (v/v) were added to stop the interaction. Supernatants were then filtered through $80-\mu \mathrm{m}$ mesh and transferred into $5 \mathrm{ml}$-polystyrene tubes (Falcon $\left.{ }^{\circledR}\right)$. After addition of $4 \mu \mathrm{l}$ of the SYBR ${ }^{\circledR}$ green (10X final concentration), tubes were incubated 30 minutes at room temperature, and then hemocyte counts in the supernatant were evaluated using the flow-cytometer as described above (see § "Total and differential hemocyte counts"). Results were expressed as percentage of adhering hemocytes after exposure to FSSW or to Vibrio sp. S322.

\subsubsection{Statistical analysis}

Each group of families was produced by crossing three females with one male. Consequently, the data were analyzed using a nested model, with three families within two groups, i.e. two males ("high survival" or "resistant" and "low survival" or "susceptible"). A nested MANOVA was performed to compare hemocyte measurements of oysters (independent variables) according to three factors, families (nested), group of families (resistant vs susceptible), rearing site, and their interactions "site $x$ family groups" and "site $x$ families (nested)". Percentage or ratio data were transformed using the Arcsine transformation (arc sine of the square root) prior to analysis. The method used to discriminate between the means was Fisher's least significant difference (LSD) procedure. Results were deemed significant at $\mathrm{P}<0.05$.

\section{Results}

\subsection{Survival, growth and reproductive status of the 6 selected families}

After 89 days of rearing on site, large differences in mortality and growth were observed between families (Dégremont et al., 2005). The three selected families showing high survival (F9-34, F9-35, F9$36=$ resistant) had a mean mortality of $5.2 \%$, while the three families selected for low survival (F7-25, F7-26, F7-27= susceptible) experienced $30.6 \%$ mean mortality (Table 1). The final mean weight of the three high-survival families was equivalent to that of the low survival families $(12.5 \mathrm{~g}$ for the highsurvival families and $12.7 \mathrm{~g}$ for the low-survival families). As shown in the Table 1, the mortality level was different from one site to another; however, family groups showing high survival in one site showed high survival in all sites. Thus, relative survival appeared independent of the rearing site.

At the sampling date (mid-October), oysters from the northern site, Baie des Veys, still contained gametes. Knowing that the normal spawning period in Baie des Veys occurred sometime between August and September, gonads were assumed to be in the gamete-resorption stage. In southern sites, Ronce and Rivière d'Auray, oysters had spawned sometime in July-August and were in the gametogenic resting phase. 


\subsection{Hemocyte characteristics}

In this study, each of the six selected families in each of the three sites was analyzed for the 15 different hemocyte measurements presented in Table 2.

Small agranulocyte cells were the least-active cells in the hemolymph, and they represented only $16 \%$ of the total number of hemocytes; therefore, results concerning this sub-population are not presented in this study.

\subsection{Comparison of the hemocyte measurements analyzed by bi-parental families}

Seven of 15 hemocyte variables differentiated at least one family from others of the 6 analyzed (nested MANOVA, Table 2). ROS production was the most notably-affected hemocyte variable. As an example, Fig. 3 presents results of ROS production by untreated granulocytes (incubated in sterile sea water) obtained for the six families analyzed, regardless of the site.

\subsection{Comparison of the hemocyte measurements between the high-survival (resistant) and low-survival (susceptible) families}

Seven of 15 hemocyte variables differentiated families with low survival from families with high survival (Table 3). Oysters from high-survival families had a higher mean hyalinocyte concentration (Fig. 4), and smaller granulocytes than did oysters with low survival (Fig. 5). Granulocytes of low-survival oysters had a higher mean ROS production in FSSW (Fig. 6) and were more inhibited by the Vibrio sp. S322 (Fig. 7).

\subsection{Differences in hemocyte measurements analyzed by rearing site}

Analysis of site effects showed that 13 of the 15 measured variables were statistically different between sites (Table 3). Oysters reared in Baie des Veys had nearly twice the concentration of hyalinocytes, approximately $7.9 \times 10^{5}$ cells per $\mathrm{ml}$, compared to Rivière d'Auray and Ronce where hyalinocytes averaged $4.1 \times 10^{5}$ cells per $\mathrm{ml}$ (Fig. 4); Granulocytes were larger (FSC $=456$ A.U.) in oysters from Baie des Veys than in oysters from Rivière d'Auray or Ronce (FSC $=368$ and 373 A.U., respectively, Fig. 5); The ROS production of granulocytes in FSSW was twice as high in oysters from Baie des Veys (686 A.U.) as in oysters from Ronce (318 A.U.) or Rivière d'Auray (372 A.U., Fig. 6); Granulocyte ROS production was inhibited by Vibrio sp. S322 in oysters reared in Ronce or Rivière d'Auray (ratio < 1; Fig. 7) but not in Baie des Veys (ratio = 1.06). Although significant differences were observed between sites for hemocyte adhesion when incubated with FSSW, the range of variation was low; from $88.2 \%$ in Rivière d'Auray to $95.9 \%$ in Ronce (Fig. 8a). However, hemocyte adhesion was clearly more sensitive to the cytotoxic effect of the Vibrio sp. S322 in Rivière d'Auray than in Baie des Veys and in Ronce (Fig. 8b).

\subsection{Interaction of site and bi-parental family and site and selected high- and low- survival families,}

Two of 15 analyzed variables showed a statistically-significant interaction between rearing site and family group (Table 3): hyalinocyte ROS production activated by zymosan particles and adhesion of hemocytes exposed to Vibrio sp. S322.

Three of 15 hemocyte variables showed a statistically-significant interaction between rearing site and bi-parental family (Table 2): inhibition of ROS production by granulocytes and hyalinocytes exposed to Vibrio sp. S322, and adhesion of hemocytes incubated in FSSW. 


\section{Discussion}

The objective of this study was to compare the hemocyte characteristics - morphological and functional - of oysters from six bi-parental families reared at three different experimental sites along the French coast during summer and to answer two main questions.

The first question addressed was, "do oyster hemocyte characteristics have a genetic basis, independent of environmental conditions and gametogenic cycle?" To address this question, hemocyte characteristics of the six bi-parental families in this experiment were compared, regardless of the rearing site. This analysis showed that 7 of the 15 hemocyte variables differentiated at least one family from others of the 6 analyzed. Moreover, only 3 of 15 variables showed a significant interaction between site and family. ROS production was the most notably different between families under all incubation conditions. Thus, a genetic bases determining hemocyte characteristics of oysters, and especially for ROS production, is implied. The variations in ROS production observed may result from variations in activities of the enzymes involved in the production (NADPH-oxidase, NO synthase) or in the detoxification (superoxide dismutase, catalase, gluthation peroxidase) of these molecules. Indeed, the genetic basis for the ROS-detoxification mechanism has been recently reported in the mollusk Biomphalaria glabrata (Goodall et al., 2004; Zelck, Von Janowsky, 2004) and currently is being investigated with oysters in our laboratory. Expression of genes involved in ROS detoxification has been shown to be modulated in oysters by environmental factors, such as hypoxia and PAH exposures (Boutet et al., 2004; David et al., 2005).

The second question addressed was, "does selection of families for high or low survival to summer mortality lead to different hemocyte characteristics" and, if so "could these different hemocyte characteristics explain the observed differences of survival?"

Although the number of resistant (high-survival) and susceptible (low- survival) families was low (three in each group), six of the 15 hemocyte variables differentiated the two groups statistically. Moreover, ANOVA results showed few significant interactions between site and survival group (resistant/ susceptible). This means that, except for the adhesion test, resistant and susceptible family groups respond in the same way regardless of the site. Thus, genetic selection based on survival performance can change hemocyte characteristics of $\underline{\underline{C}}$. gigas.

A more fundamental question was whether or not high survival during the summer mortality period could be attributed to differences in hemocytes: the hemocyte profile of resistant oysters was compared to that of susceptible oyster families. High-survival families had higher hemocyte counts, lower inhibition of the ROS production by the Vibrio sp. S322, and lower susceptibility to bacteria in the adhesion test. These hemocyte attributes could be hypothesized to confer better capacity for high survival when challenged by pathogenic bacteria, for example. Resistant oysters, however, also had smaller granulocytes and lower ROS production. The latter parameter has been observed to be modulated by acute stress (Lacoste et al., 2002), infection by $\underline{V}$. aestuarianus (Labreuche et al., 2006b; Labreuche et al., 2006a), and dietary changes (Delaporte et al., in press). Cellular ROS content also depends on ROS detoxification capacities and respiration processes in other organisms (Sheehan, Power, 1999; Batandier et al., 2002; Cadenas, 2004; Keller et al., 2004; Manduzio et al., 2005). When suppression-substractive hydridization (SSH) techniques were used during the MOREST program (Huvet et al., 2004), resistant and susceptible oysters were shown to express differentially a cavortin-like gene, later characterized as an hemocyte $\mathrm{Cu} / \mathrm{Zn}$ superoxide dismutase (SOD) gene (Gonzalez et al., 2005). In their experiments, these authors showed that resistant oysters had a higher $\mathrm{Cu} / \mathrm{Zn}$ SOD gene expression than susceptible oysters. Accordingly, gene expression is thought to contribute to ROS detoxification; this may partially explained the difference in ROS production in our experiment between resistant and susceptible oysters. Furthermore, one may speculate that selection for one or more enzymes involved in ROS production and/or detoxification may have concurrently occurred with selection for summer mortality survival.

Nevertheless, we call attention to the fact that hemocyte measurements were analyzed for the survivors of the selected families after the summer mortality event; the mean mortality of susceptible oysters was approximately $30 \%$, and $5 \%$ in resistant families. In addition, the criterion for selection was survival during the first summer, without knowledge of the exact cause of mortality. Thus, it is important to remain prudent when trying to link hemocyte characteristics with oyster survival during the period of summer mortality.

Genetic selection, however, does not overcome all environmental influences. Indeed, this study demonstrates that rearing site strongly affected the hemocyte characteristics of all families of oysters. 
Thirteen of the hemocyte variables measured were affected statistically by rearing site. ANOVA results were often influenced by the values collected in Baie des Veys. These observed differences can probably be attributed to variations in environmental conditions and reproductive cycles between rearing sites. It is well known that environmental conditions strongly influence hemocyte characteristics of bivalves, including temperature (Oliver, Fisher, 1995; Fisher et al., 1996; Carballal et al., 1998) and chemical contaminants (Fisher et al., 1990; Fisher et al., 2000; Oliver et al., 2001; Auffret et al., 2002). Hemocytes are multi-functional cells involved in various activities: wound and shell repair, nutrition, digestion, transport of nutrients, defense, etc. (Cheng, 1996). Therefore, hemocyte characteristics are also modified or modulated by the physiological status of the oyster, especially during the reproductive cycle, and by the quantity and quality of trophic resources (Delaporte et al., 2003; Hégaret et al., 2004).

Although several biotic and abiotic factors could be invoked to explain the site effect on the hemocytes, two biological major differences can be highlighted between Baie des Veys and the two southern sites. First, the growth in Baie des Veys was appreciably higher than in Ronce or Rivière d'Auray. Such growth performance (somatic and germinal) suggests that trophic conditions in Baie des Veys were favourable for oysters, in terms of energy input. Second, although oysters in Baie des Veys have active gametogenesis, only partial and incomplete spawning was observed, probably attributable to lower temperatures as compared to southern sites (Berthelin et al., 2000). At the sampling date, one month after the normal spawning period in this area, oysters from Baie des Veys still contained gonads and underwent gonad resorption; whereas, in Ronce and Rivière d'Auray, oysters were in the reproductive resting phase (spawning occurred in July-August). As hemocytes are known to participate in gonad resorption as transporting cells (Cheng, 1996), re-cycling processes of the non-spawned gamete tissues are likely to result in additional energy for circulating hemocytes. Consequently, the better energetic balance (trophic conditions and gamete resorption) of the oysters reared in Baie des Veys could partially explain why hemocytes were more numerous, metabolically active, (higher ROS production level) and less susceptible to the pathogenic Vibrio sp. S322 in vitro.

Overall, this study demonstrated that the hemocyte characteristics of the oyster $\underline{\mathrm{C}}$. gigas are influenced by a complex balance of genetic heritage and factors related to environment. We showed consistent hemocyte characteristics in oyster families selected for survival to summer mortality, regardless of the environmental conditions and gametogenic status. Further, this work highlighted the difficulty in easily linking oyster survival during summer mortality to hemocyte profile alone as a health indicator. There is no doubt that broader approach, with in-depth examination of oyster physiology will help to find other relevant health indicators explaining oyster survival during summer mortality events.

\section{Acknowledgement}

This work was supported by the MOREST national program and partially funded by IFremer, Brest, France (contract IFremer/ LEMAR, IF 01.2.521.409). We greatly thank Dr J.-L. Nicolas for supplying the Vibrio sp., strain S322. Suggestions and comments of Dr Aswani Volety, Dr Susan Ford and Dr Gary Wikfors on the original version of the manuscript were greatly appreciated. Contribution $\mathrm{N}^{\circ} \mathrm{XXX}$ of the IUEM, European Institute for Marine Studies (Brest, France). 


\section{References}

Auffret, M., Mujdzic, N., Corporeau, C., Moraga, D., 2002. Xenobiotic-induced immunomodulation in the European flat oyster, Ostrea edulis. Mar. Environ. Res. 54, 585-589.

Bachère, E., Hervio, D., Mialhe, E., 1991. Luminol-dependent chemiluminescence by hemocytes of two marine bivalves, Ostrea edulis and Crassostrea gigas. Dis. Aquat. Organ. 11, 173-180.

Bass, D.A., Parce, J.W., Dechatelet, L.R., Szejda, P., Seeds, M.C., Thomas, M., 1983. Flow cytometric studies of oxidative product formation by neutrophils: a graded response to membrane stimulation. J. Immunol. 130, 1910-1917.

Batandier, C., Fontaine, E., Keriel, C., Leverve, X.M., 2002. Determination of mitochondrial reactive oxygen species: methodological aspects. J. Cell. Mol. Med. 6, 175-187.

Beattie, J.H., Chew, K.K., Hershberger, W.K., 1980. Differential survival of selected strains of Pacific oysters (Crassostrea gigas) during summer mortality. Proceeding of the National Shellfisheries Association 70, 184-189.

Berthelin, C., Kellner, K., Mathieu, M., 2000. Storage metabolism in the Pacific oyster (Crassostrea gigas) in relation to summer mortalities and reproductive cycle (west coast of France). Comp. Biochem. Phys. B 125, 359-369.

Boutet, I., Tanguy, A., Moraga, D., 2004. Response of the Pacific oyster Crassostrea gigas to hydrocarbon contamination under experimental conditions. Gene 329, 147-157.

Cadenas, E., 2004. Mitochondrial free radical production and cell signaling. Mol. Aspects Med. 25, 1726.

Carballal, M.J., Villalba, A., Lopez, C., 1998. Seasonal variation and effects of age, food availability, size, gonadal development, and parasitism on the hemogram of Mytilus galloprovincialis. J. Invertebr. Pathol. 72, 304-312.

Cheney, D.P., MacDonald, B.F., Elston, R.A., 2000. Summer mortality of pacific oysters, Crassostrea gigas (Thunberg): Initial findings on multiple environmental stressors in Puget Sound, Washington, 1998. J. Shellfish Res. 19, 353-359.

Cheng, T.C., 1996. Hemocytes: Forms and functions. In: Kennedy, V.S., Newell, R.I.E., Eble, A.F. (Eds.), The Eastern Oyster Crassostrea virginica. Maryland Sea Grant Book, College Park, MD, USA, pp. 299-333.

Choquet, G., Soudant, P., Lambert, C., Nicolas, J.-L., Paillard, C., 2003. Reduction of adhesion properties on Ruditapes philippinarum hemocytes exposed to Vibrio tapetis. Dis. Aquat. Organ. 57, 109-116.

David, E., Tanguy, A., Pichavant, K., Moraga, D., 2005. Response of the Pacific oyster Crassostrea gigas to hypoxia exposure under experimental conditions. Febs J 272, 5635-5652.

Degremont, L., Ernande, B., Bedier, E., Boudry, P., 2007. Summer mortality of hatchery-produced Pacific oyster spat (Crassostrea gigas). I. Estimation of genetic parameters for survival and growth. Aquaculture 262, 41.

Dégremont, L., 2003. Etude des bases génétiques de la mortalité estivale et des relations avec la croissance chez les juvéniles de l'huître creuse Crassostrea gigas. Phd Thesis. University of Caen (France). 333 pp. (in French).

Dégremont, L., Boudry, P., Soletchnik, P., Bédier, E., Ropert, M., Huvet, A., Moal, J., Samain, J.F., 2003. Genetic basis of summer mortality in juvenile cupped oysters. (abstract). J. Shellfish Res. 22, 327.

Dégremont, L., Bédier, E., Soletchnik, P., Ropert, M., Huvet, A., Moal, J., Samain, J.-F., Boudry, P., 2005. Relative importance of family, site, and field placement timing on survival, growth, and yield of hatchery-produced Pacific oyster spat (Crassostrea gigas). Aquaculture 249, 213-229.

Delaporte, M., Soudant, P., Lambert, C., Moal, J., Pouvreau, S., Samain, J.F., 2006. Impact of food availability on energy storage and defense related hemocyte parameters of the Pacific oyster Crassostrea gigas during an experimental reproductive cycle. Aquaculture 254, 571-582.

Delaporte, M., Chu, F.E., Langdon, C., Soudant, P., Moal, J., Lambert, C., Samain, J.F., in press. Changes in biochemical and hemocyte parameters of the Pacific oysters Crassostrea gigas fed T-Iso supplemented with lipid emulsions rich in 20:5n-3. J. Exp. Mar. Biol. Ecol.

Delaporte, M., Soudant, P., Moal, J., Lambert, C., Quere, C., Miner, P., Choquet, G., Paillard, C., Samain, J.F., 2003. Effect of a mono-specific algal diet on immune functions in two bivalve species - Crassostrea gigas and Ruditapes philippinarum. J. Exp. Biol. 206, 3053-3064.

Ernande, B., Clobert, J., McCombie, H., Boudry, P., 2003. Genetic polymorphism and trade-offs in the early life-history strategy of the Pacific oyster, Crassotrea gigas (Thunberg, 1795): a quantitative genetic study. J. Evolution. Biol. 16, 399-414. 
Ernande, B., Boudry, P., Clobert, J., Haure, J., 2004. Plasticity in resource allocation based life history traits in the Pacific oyster, Crassostrea gigas. I. Spatial variation in food abundance. J. Evolution. Biol. 17, 342-356.

Fisher, W.S., Wishkovsky, A., Ford, S.E., 1990. Effects of tributyltin on defense-related activities of oyster hemocytes. Arch. Environ. Con. Tox. 19, 354-360.

Fisher, W.S., Leah, M.O., Edwards, P., 1996. Hematologic and serologic variability of eastern oysters from Apalachicola Bay, Florida. J. Shellfish Res. 15, 555-564.

Fisher, W.S., Oliver, L.M., Winstead, J.T., Long, E.R., 2000. A survey of oysters Crassostrea virginica from Tampa Bay, Florida: associations of internal defense measurements with contaminant burdens. Aquat. Toxicol. 51, 115-138.

Ford, S.E., Ashton-Alcox, K.A., Kanaley, S.A., 1994. Comparative cytometric and microscopic analyses of oyster hemocytes. J. Invertebr. Pathol. 64, 114-122.

Glude, J.B., 1974. A summary report of Pacific coast oyster mortality investigations 1965-1972., Proc. 3rd U.S. Japan Meet. Aquac. Spec. Publ. Fish. Agency, Jap. Gouv.\& Jap. Sea Reg. Fish. Res. Lab. Nigata, Tokyo, pp. 1-28.

Goedken, M., De Guise, S., 2004. Flow cytometry as a tool to quantify oyster defence mechanisms. Fish Shellfish Immunol. 16, 539-552.

Gonzalez, M., Romestand, B., Fievet, J., Huvet, A., Lebart, M.-C., Gueguen, Y., Bachere, E., 2005. Evidence in oyster of a plasma extracellular superoxide dismutase which binds LPS. Biochem. Biophys. Res. Commun. 338, 1089.

Goodall, C.P., Bender, R.C., Broderick, E.J., Bayne, C.J., 2004. Constitutive differences in Cu/Zn superoxide dismutase mRNA levels and activity in hemocytes of Biomphalaria glabrata (Mollusca) that are either susceptible or resistant to Schistosoma mansoni (Trematoda). Mol. Biochem. Parasit. 137, 321-328.

Goulletquer, P., Soletchnik, P., Le Moine, O., Razet, D., Geairon, P., Faury, N., Taillade, S., 1998. Summer mortality of the Pacific cupped oyster Crassostrea gigas in the Bay of MarennesOléron (France). ICES Statutory Meeting, Population Biology, Mariculture Committee CM 1998 / CC, pp. 14-20.

Hégaret, H., Wikfors, H.G., Soudant, P., 2003a. Flow-cytometric analysis of haemocytes from eastern oysters, Crassostrea virginica, subjected to a sudden temperature elevation. I: Haemocyte types and morphology. J. Exp. Mar. Biol. Ecol. 293, 237-248.

Hégaret, H., Wikfors, H.G., Soudant, P., 2003b. Flow-cytometric analysis of haemocytes from eastern oysters, Crassostrea virginica, subjected to a sudden temperature elevation. II. Haemocyte functions: aggregation, viability, phagocytosis, and respiratory burst. J. Exp. Mar. Biol. Ecol. 293, 249-265.

Hégaret, H., Wikfors, H.G., Soudant, P., Delaporte, M., Alix, J.H., Smith, B.C., Dixon, M.S., Quéré, C., Le Coz, J.R., Paillard, C., Moal, J., Samain, J.F., 2004. Immunological competence of eastern oysters, Crassostrea virginica, fed different microalgal diets and challenged with a temperature elevation. Aquaculture 234, 541-560.

Hershberger, W.K., Perdue, J.A., Beattie, J.H., 1984. Genetic selection and systematic breeding in Pacific oyster culture. Aquaculture 39, 237-245.

Huvet, A., Herpin, A., Degremont, L., Labreuche, Y., Samain, J.F., Cunningham, C., 2004. The identification of genes from the oyster Crassostrea gigas that are differentially expressed in progeny exhibiting opposed susceptibility to summer mortality. Gene 343, 211-220.

Keller, M., Sommer, A.M., Portner, H.O., Abele, D., 2004. Seasonality of energetic functioning and production of reactive oxygen species by lugworm (Arenicola marina) mitochondria exposed to acute temperature changes. J. Exp. Biol. 207, 2529-2538.

Koganezawa, A., 1974. Present status of studies on the mass mortality of cultured oysters in Japan and its prevention., 3rd U.S. Japan Meet. Aquac. Spec. Publ. Fish. Agency, Jap. Gouv. \& Jap. Sea Reg. Fish. Res. Lab. Nigata, Tokyo, pp. 29-34.

Labreuche, Y., Soudant, P., Goncalves, M., Lambert, C., Nicolas, J.L., 2006a. Effects of extracellular products from the pathogenic Vibrio aestuarianus strain 01/32 on lethality and cellular immune responses of the oyster Crassostrea gigas. Dev. Comp. Immunol. 30, 367-379.

Labreuche, Y., Lambert, C., Soudant, P., Boulo, V., Huvet, A., Nicolas, J.L., 2006b. Cellular and molecular hemocyte responses of the Pacific oyster, Crassostrea gigas, following bacterial infection with Vibrio aestuarianus strain 01/32. Microbes Infect. 8, 2715-2724.

Lacoste, A., Malham, S.K., Gelebart, F., Cueff, A., Poulet, S.A., 2002. Stress-induced immune changes in the oyster Crassostrea gigas. Dev. Comp. Immunol. 26, 1-9. 
Lambert, C., Nicolas, J.-L., 1998. Specific inhibition of chemiluminescent activity by pathogenic Vibrios in hemocytes of two marine bivalves: Pecten maximus and Crassostrea gigas. J. Invertebr. Pathol. 71, 53-63.

Lambert, C., Nicolas, J.L., Bultel, V., 2001. Toxicity to bivalve hemocytes of pathogenic vibrio cytoplasmic extract. J. Invertebr. Pathol. 77, 165-172.

Lambert, C., Soudant, P., Choquet, G., Paillard, C., 2003. Measurement of Crassostrea gigas hemocyte oxidative metabolism by flow cytometry and the inhibiting capacity of pathogenic vibrios. Fish Shellfish Immunol. 15, 225-240.

Manduzio, H., Rocher, B., Durand, F., Galap, C., Leboulenger, F., 2005. The point about oxidative stress in molluscs. I.S.J. 2, 91-104.

Marie, D., Partensky, F., Vaulot, D., Brussaard, C.P.D., 1999. Enumeration of phytoplankton, bacteria, and viruses in marine samples. In: Robinson, J.P., Darzynkiewicz, Z., Dean, P.N., Orfao, A., Rabinovitch, P., Stewart, C., Tanke, H.J., Wheeless, L. (Eds.), Current protocols in cytometry. John Wiley \& Sons, Inc., New York. N.Y., pp. 11.11.11-11.11.15.

Nicolas, J.L., Corre, S., Gauthier, G., Robert, R., Ansquer, D., 1996. Bacterial problems associated with scallop (Pecten maximus) larval culture. Dis. Aquat. Organ. 27, 67-76.

Oliver, L.M., Fisher, W.S., 1995. Comparative form and function of oyster Crassostrea virginica hemocytes from Apalachicola Bay, Florida and Chesapeake Bay (Virginia). Dis. Aquat. Organ. 22, 217-225.

Oliver, L.M., Fisher, W.S., Winstead, J.T., Hemmer, B.L., Long, E.R., 2001. Relationships between tissue contaminants and defense-related characteristics of oysters (Crassostrea virginica) from five Florida bays. Aquatic Toxicology 55, 203-222.

Sheehan, D., Power, A., 1999. Effect of seasonality on xenobiotic and antioxidant defence mechanisms of bivalve molluscs. Comp. Biochem. Phys. C 123, 193-199.

Soletchnik, P., Lambert, C., Costil, K., 2005. Summer mortality of Crassostrea gigas (Thunberg) in relation to environmental rearing conditions. J. Shellfish Res. 24, 197-207.

Soletchnik, P., Le Moine, O., Faury, N., Razet, D., Geairon, P., Goulletquer, P., 1999. Mortalité de I'huître Creuse Crassostrea gigas dans le bassin de Marennes-Oléron: Etude de la variabilité spatiale de son environnement et de sa biologie par un système d'informations géographiques (SIG). Aquat. Living Resour. 12, 131-143.

Soletchnik, P., Ropert, M., Huvet, A., Moal, J., Degrémont, L., Bedier, E., Bouget, M., Dubois, B., Martin, J.L., Enriquez Diaz, M., Faury, N., Le Moine, O., Renault, T., Gagnaire, B., Samain, J.F., 2003. Characterization of summer mortalities of Crassostrea gigas oyster in France in relation to environmental parameters (abstract). J. Shellfish Res. 22, 354.

Volety, A.K., Chu, F.L., 1995. Suppression of chemiluminescence of eastern oyster (Crassostrea virginica) hemocytes by the protozoan parasite Perkinsus marinus. Dev. Comp. Immunol. 19, 135-142.

Waechter, M., Le Roux, F., Nicolas, J.L., Marissal, E., Berthe, F., 2002. Characterization of pathogenic bacteria of the cupped oyster Crassostrea gigas. C. R. Biologies 325, 231-238.

Zelck, U.E., Von Janowsky, B., 2004. Antioxidant enzymes in intramolluscan Schistosoma mansoni and ROS-induced changes in expression. Parasitology 128, 493-501. 
Table 1: Mean mortality (\%) of oysters evaluated in October 2001 after 89 days of rearing for the 6 selected families according to the rearing site.

\begin{tabular}{|c|c|c|c|c|c|}
\hline Mortality \% & Families & $\begin{array}{c}\text { Baies des } \\
\text { Veys }\end{array}$ & $\begin{array}{l}\text { Rivière } \\
\text { d'Auray }\end{array}$ & Ronce & All sites \\
\hline "Susceptible" & F7-25 & 19.6 & 56.0 & 57.6 & \\
\hline Low survival & F7-26 & 8.7 & 38.1 & 28.7 & \\
\hline group & F7-27 & 6.9 & 31.3 & 28.9 & \\
\hline "Resistant" & F9-34 & 3.6 & 10.3 & 4.2 & \\
\hline High survival & F9-35 & 4.1 & 9.0 & 4.0 & \\
\hline \multirow[t]{4}{*}{ group } & F9-36 & 2.5 & 6.2 & 3.1 & \\
\hline & Mean susceptible & 11.8 & 41.8 & 38.4 & 30.6 \\
\hline & Mean resistant & 3.4 & 8.5 & 3.8 & 5.2 \\
\hline & Total mean & 7.6 & 25.1 & 21.1 & 17.9 \\
\hline
\end{tabular}


Table 2: Statistical analysis (nested MANOVA) comparing the hemocyte parameters of oysters from six different families (F7-25, 26, 27 and F9-34, 35, 36) $(\mathrm{n}=9)$ (Gr: granulocyte; Hy: hyalinocyte; FSSW: filtered sterile sea-water; Zym: zymosan; Vibrio: Vibrio sp. S322; ROS: reactive oxygen species; - : no significant differences, $*$ : $p<0.05, * *: p<0.01 ; * * *: p<0.001)$.

\begin{tabular}{|c|c|c|c|c|c|c|c|c|}
\hline Parameters & $\begin{array}{c}\text { Family effect } \\
\text { (nested) }\end{array}$ & F7-25 & F7-26 & F7-27 & F9-34 & F9-35 & F9-36 & $\begin{array}{l}\text { Interaction } \\
\text { site/family }\end{array}$ \\
\hline \multicolumn{9}{|c|}{$\begin{array}{l}\text { 1. Concentrati } \\
\text { on }\end{array}$} \\
\hline 1) $\mathrm{Gr}$ & - & $\begin{array}{l}1.19 \\
10^{5}\end{array}$ & $\begin{array}{l}1.39 \\
10^{5}\end{array}$ & $\begin{array}{l}1.34 \\
10^{5}\end{array}$ & $\begin{array}{l}1.15 \\
10^{5}\end{array}$ & $\begin{array}{l}1.31 \\
10^{5}\end{array}$ & $\begin{array}{l}1.79 \\
10^{5}\end{array}$ & - \\
\hline 2) Hy & - & $\begin{array}{l}4.60 \\
10^{5}\end{array}$ & $\begin{array}{l}4.74 \\
10^{5}\end{array}$ & $\begin{array}{l}4.51 \\
10^{5}\end{array}$ & $\begin{array}{l}5.48 \\
10^{5}\end{array}$ & $\begin{array}{l}6.46 \\
10^{5}\end{array}$ & $\begin{array}{l}6.62 \\
10^{5}\end{array}$ & - \\
\hline 3) Total & - & $\begin{array}{l}7.02 \\
10^{5}\end{array}$ & $\begin{array}{l}7.69 \\
10^{5}\end{array}$ & $\begin{array}{l}6.93 \\
10^{5}\end{array}$ & $\begin{array}{l}7.75 \\
10^{5}\end{array}$ & $\begin{array}{l}9.40 \\
10^{5}\end{array}$ & $\begin{array}{l}9.55 \\
10^{5}\end{array}$ & - \\
\hline
\end{tabular}

\section{Morphology}

\begin{tabular}{lcccccccc} 
4) granularity Gr & - & 472 & 456 & 465 & 455 & 446 & 463 & - \\
5) granularity Hy & - & 62 & 64 & 62 & 63 & 63 & 68 & - \\
6) Size Gr & $* *$ & 462 & 415 & 411 & 356 & 409 & 341 & - \\
7) Size Hy & - & 383 & 392 & 374 & 386 & 380 & 395 & - \\
\hline 3. ROS & & & & & & & &
\end{tabular}

\section{ROS
production}

\begin{tabular}{|c|c|c|c|c|c|c|c|c|}
\hline 8) FSSW Gr & ** & 562 & 608 & 416 & 355 & 362 & 450 & - \\
\hline 9) FSSW Hy & $*$ & 435 & 488 & 368 & 398 & 389 & 519 & - \\
\hline 10) Zym Gr & *** & 1.40 & 1.58 & 1.93 & 1.78 & 1.55 & 1.54 & - \\
\hline 11) Zym Hy & ** & 1.00 & 1.07 & 1.2 & 1.22 & 1.16 & 1.04 & - \\
\hline 12) Vibrio $\mathrm{Gr}$ & *** & 0.92 & 0.68 & 0.94 & 1.07 & 1.01 & 0.85 & * \\
\hline 13) Vibrio Hy & *** & 0.79 & 0.55 & 0.68 & 0.87 & 0.78 & 0.67 & ** \\
\hline \multicolumn{9}{|c|}{ 4. Adhesion } \\
\hline 14) FSSW & _ & 80.1 & 78.2 & 80.4 & 85.3 & 83.0 & 80.9 & ** \\
\hline 15) Vibrio & - & 91.9 & 92.5 & 92.9 & 91.2 & 90.9 & 92.1 & - \\
\hline
\end{tabular}

Foot note:

Concentration in cells $\mathrm{mL}^{-1}:$ 1) granulocytes, 2) hyalinocytes, 3) total hemocytes.

Granularity in arbitrary units (SSC value): 4) granulocytes, 5) hyalinocytes.

Size in arbitrary units (FSC value): 6) granulocytes, 7) hyalinocytes.

ROS production in arbitrary units (FL1 value) at 180 min in FSSW: 8) granulocytes, 9) hyalinocytes.

ROS production: ratio FL1 level of 10) granulocytes or 11) hyalinocytes + zym to control (+FSSW) at $t=120 \mathrm{~min}$.

ROS production: ratio of FL1 level of 12) granulocytes or 13) hyalinocytes + Vibrio sp. S322 to control $(+F S S W)$ at $t=180$ min

Adhesion : Percentage of adherent hemocytes after 3h exposure to FSSW (14) and Vibrio sp. S322 (15) 
Table 3: Statistical analysis (MANOVA) comparing the hemocyte parameters of oysters according to the rearing site ( $\mathrm{n}=18$ ) and according to high survival (resistant) and low survival (susceptible) oyster families $(n=27)$. (Gr: granulocyte; Hy: hyalinocyte; FSSW: filtered sterile sea-water; Zym: zymosan; Vibrio: Vibrio sp. S322; ROS: reactive oxygen species; - : no significant differences, $\quad *$ : $p<0.05, \quad * *$ : $p<0.01 ; * \star *$ : $p<0.001$; Letters indicate significant differences between rearing sites).

\begin{tabular}{|c|c|c|c|c|c|c|c|c|}
\hline Parameters & $\begin{array}{l}\text { Site } \\
\text { effect }\end{array}$ & $\begin{array}{c}\text { Baies des } \\
\text { Veys }\end{array}$ & $\begin{array}{l}\text { Rivière } \\
\text { d'Auray }\end{array}$ & Ronce & $\begin{array}{l}\text { Resistant vs } \\
\text { susceptible }\end{array}$ & Resistant & $\begin{array}{l}\text { Susceptibl } \\
\text { e }\end{array}$ & $\begin{array}{l}\text { interaction } \\
\text { site/ family }\end{array}$ \\
\hline \multicolumn{9}{|l|}{ Concentration } \\
\hline 1) $\mathrm{Gr}$ & - & $1.4110^{5}$ & $1.5110^{5}$ & $1.1710^{5}$ & - & $1.4210^{5}$ & $1.3110^{5}$ & - \\
\hline 2) $\mathrm{Hy}$ & *** & $7.8810^{5} \mathbf{b}$ & $4.1610^{5} \mathbf{a}$ & $4.1510^{5} \mathbf{a}$ & $* * *$ & $6.1910^{5}$ & $4.6210^{5}$ & - \\
\hline 3) Total & $* * *$ & $1.0710^{6} \mathbf{b}$ & $6.9610^{5} a$ & $6.4910^{5} a$ & * & $8.9010^{5}$ & $7.2110^{5}$ & - \\
\hline \multicolumn{9}{|l|}{ Morphology } \\
\hline 4) granularity Gr & $* * *$ & $401 \mathbf{a}$ & $516 \mathrm{c}$ & $460 \mathrm{~b}$ & - & 455 & 464 & - \\
\hline 5) granularity Hy & ** & $66 \mathbf{b}$ & $61 \mathbf{a}$ & $63 a b$ & - & 65 & 63 & - \\
\hline 6) size $\mathrm{Gr}$ & *** & 456 b & $368 \mathbf{a}$ & $373 \mathbf{a}$ & $* * *$ & 369 & 429 & - \\
\hline 7) size Hy & *** & $402 \mathrm{c}$ & $386 \mathbf{b}$ & $367 \mathbf{a}$ & - & 387 & 383 & - \\
\hline \multicolumn{9}{|l|}{ ROS production } \\
\hline 8) FSSW Gr & *** & $686 \mathrm{~b}$ & $372 \mathbf{a}$ & $318 \mathbf{a}$ & *** & 389 & 529 & - \\
\hline 9) FSSW Hy & *** & 508 b & $431 \mathbf{a b}$ & $360 \mathbf{a}$ & - & 435 & 430 & - \\
\hline 10) Zym Gr & * & $1.74 \mathrm{~b}$ & $1.64 \mathrm{ab}$ & $1.49 \mathrm{a}$ & - & 1.62 & 1.63 & - \\
\hline 11) Zym Hy & - & 1.08 & 1.10 & 1.18 & - & 1.14 & 1.09 & * \\
\hline 12) Vibrio Gr & $* * *$ & $1.06 \mathbf{b}$ & $0.78 \mathbf{a}$ & $0.89 \mathbf{a}$ & $* * *$ & 0.98 & 0.85 & - \\
\hline 13) Vibrio Hy & * & 0.77 b & $0.67 \mathbf{a}$ & $0.74 \mathrm{ab}$ & $* *$ & 0.77 & 0.67 & - \\
\hline \multicolumn{9}{|l|}{ Adhesion } \\
\hline 14) FSSW & *** & 91.7 b & $88.2 \mathbf{a}$ & 95.9 c & - & 91.4 & 92.4 & - \\
\hline 15) Vibrio & $* * *$ & 89.4 b & $62.7 \mathrm{a}$ & $91.8 \mathrm{a}$ & * & 83.0 & 79.5 & ** \\
\hline
\end{tabular}

Foot note:

Concentration in cells $\mathrm{mL}^{-1}:$ 1) granulocytes, 2) hyalinocytes, 3) total hemocytes.

Granularity in arbitrary units (SSC value): 4) granulocytes, 5) hyalinocytes.

Size in arbitrary units (FSC value): 6) granulocytes, 7) hyalinocytes.

ROS production in arbitrary units (FL1 value) at 180 min in FSSW: 8) granulocytes, 9) hyalinocytes.

ROS production: ratio FL1 level of 10) granulocytes or 11) hyalinocytes + zym to control (+FSSW) at $t=120$ min.

ROS production: ratio of FL1 level of 12) granulocytes or 13) hyalinocytes + Vibrio sp. S322 to control $(+F S S W)$ at $t=180 \mathrm{~min}$

Adhesion : Percentage of adherent hemocytes after 3h exposure to FSSW (14) and Vibrio sp. S322 (15) 


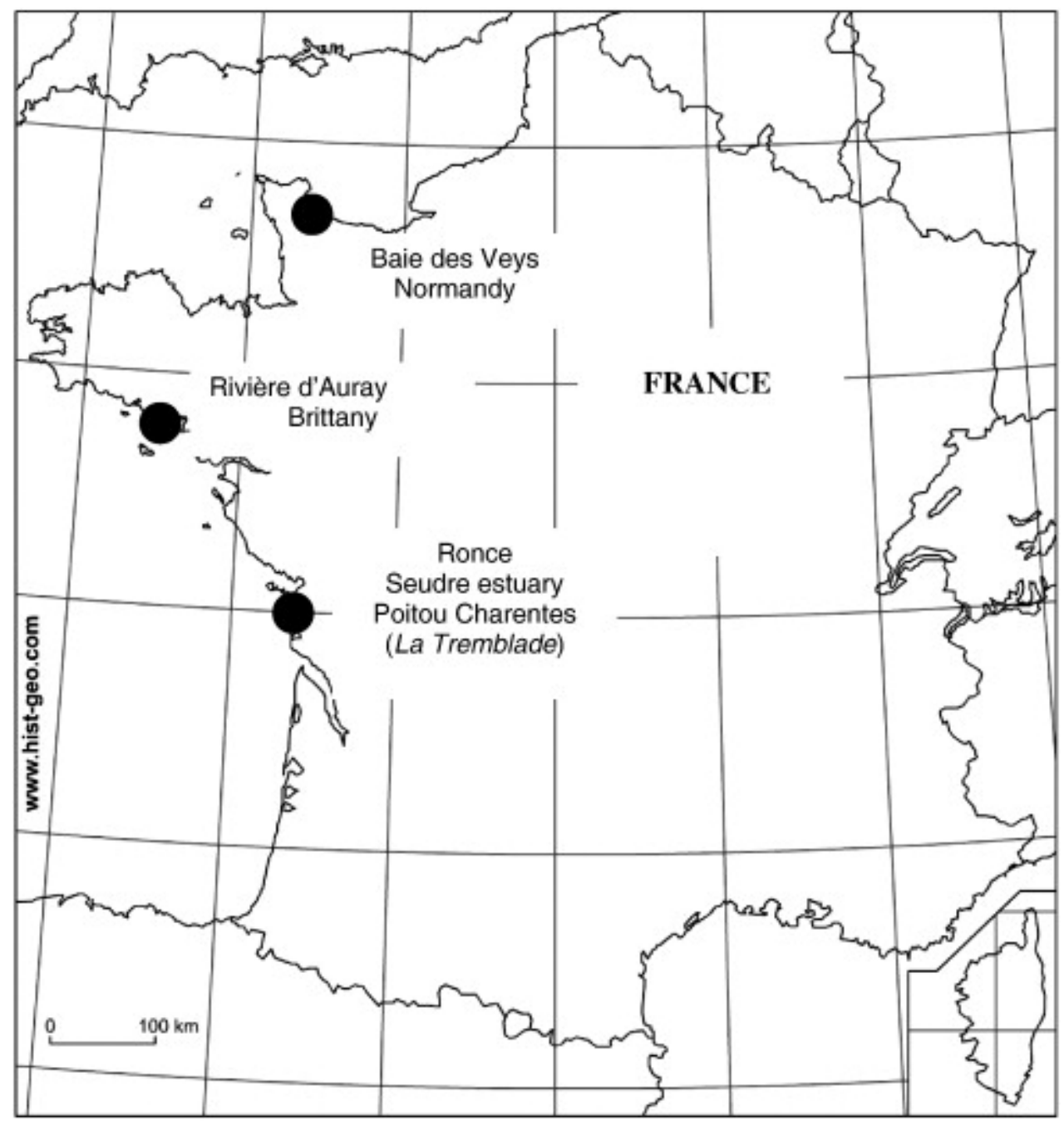

Fig. 1: Experimental sites along the Atlantic French coasts: Baie des Veys (Normandy), Rivière d'Auray (Brittany) and Ronce (Marennes-Oléron Bay, Poitou Charentes). The Ifremer hatchery is situated in La Tremblade (Poitou Charentes). The Seudre estuary flows into the MarennesOléron Bay. 


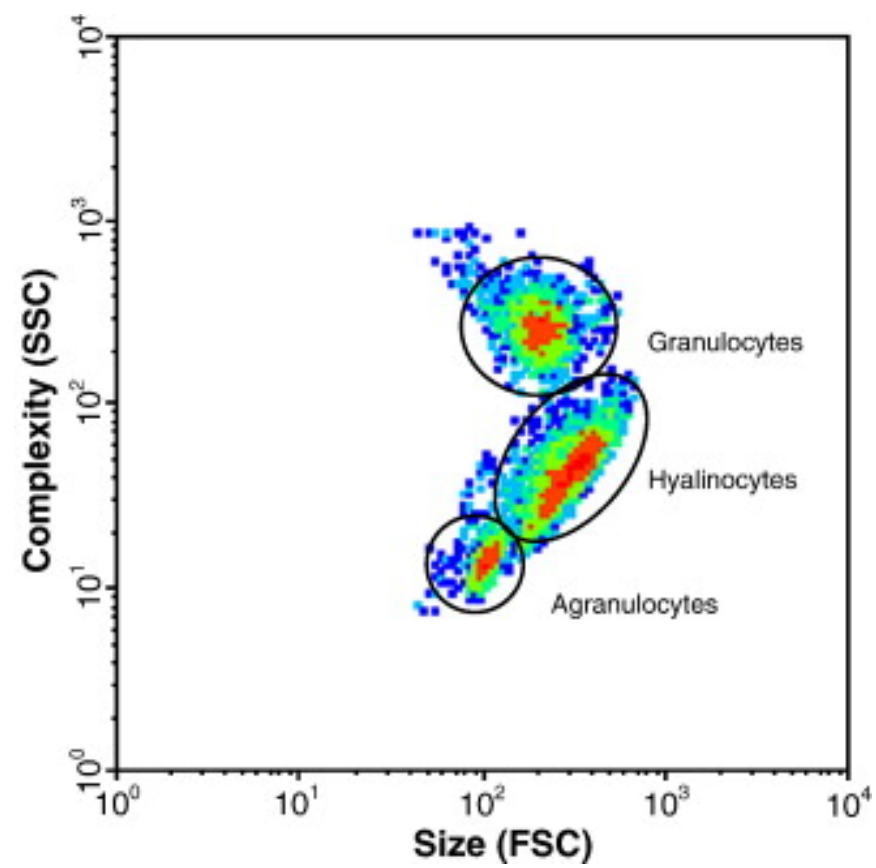

Fig. 2: Flow-cytometer density plot of $\underline{C}$. gigas hemocytes allowing the distinction of sub-populations (agranulocytes, granulocytes and hyalinocytes) according to their relative size (FSC) and complexity/ granularity (SSC).

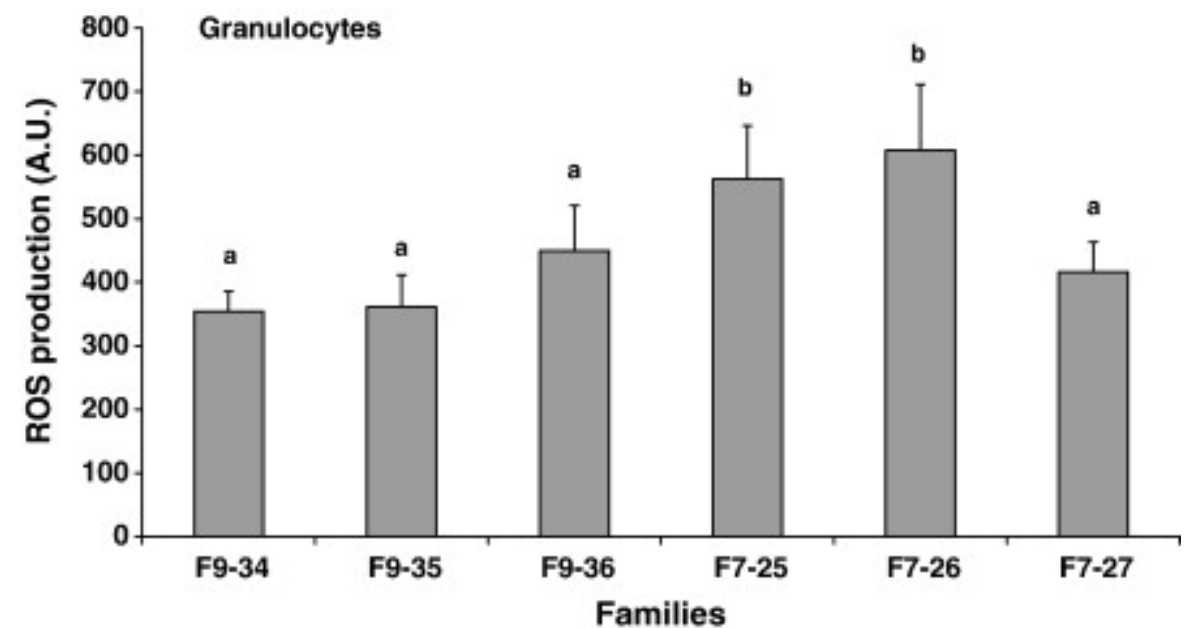

Fig. 3: Granulocyte reactive oxygen species (ROS) production in seawater, at $t=180 \mathrm{~min}$, of hemocytes (DCF fluorescence $=$ FL1 value in arbitrary detector units, Mean \pm SE, $n=3$ ) of six oyster bi-parental families (F7-25, F7-26, F7-27, F9-34, F9-35 and F9-36) after three months rearing at three different sites: Baie des Veys, Rivière d'Auray and Ronce. Letters indicate significant differences between families, nested MANOVA, $p<0.05$. 


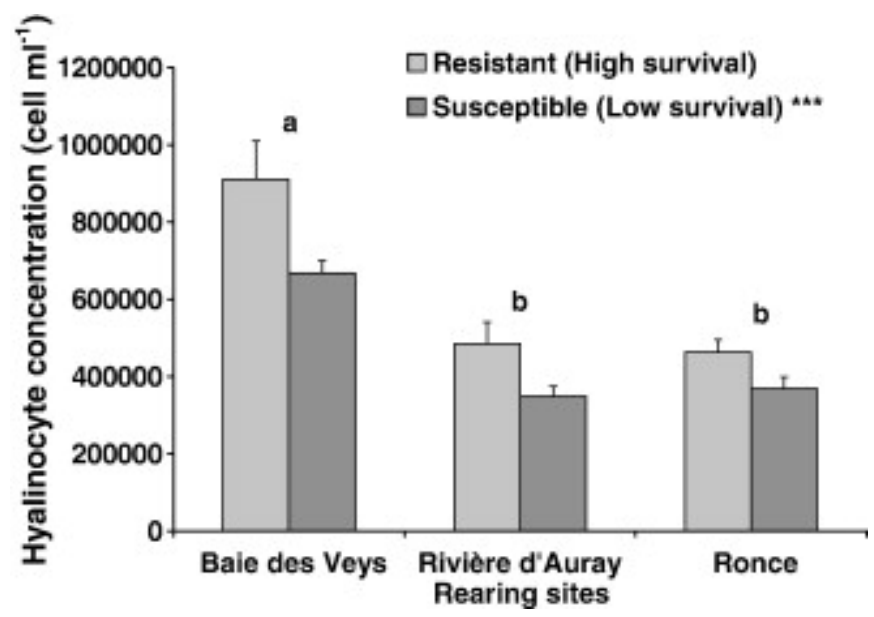

Fig. 4: Hyalinocyte concentrations (cells $\mathrm{ml}^{-1}$ ) in hemolymph of resistant (High-survival) and susceptible (Low-survival) oyster families after three months rearing at three different sites: Baie des Veys, Rivière d'Auray and Ronce (Mean $\pm S E, n=9$ ). Letters indicate significant differences between rearing sites, MANOVA, $\mathrm{p}<0.05$; * indicates significant differences between resistant (High-survival) and susceptible (Low-survival) oyster families at $p<0.05$; ** at $p<0.01,{ }^{\star * \star}$ at $p<0.001$, NS not significant.

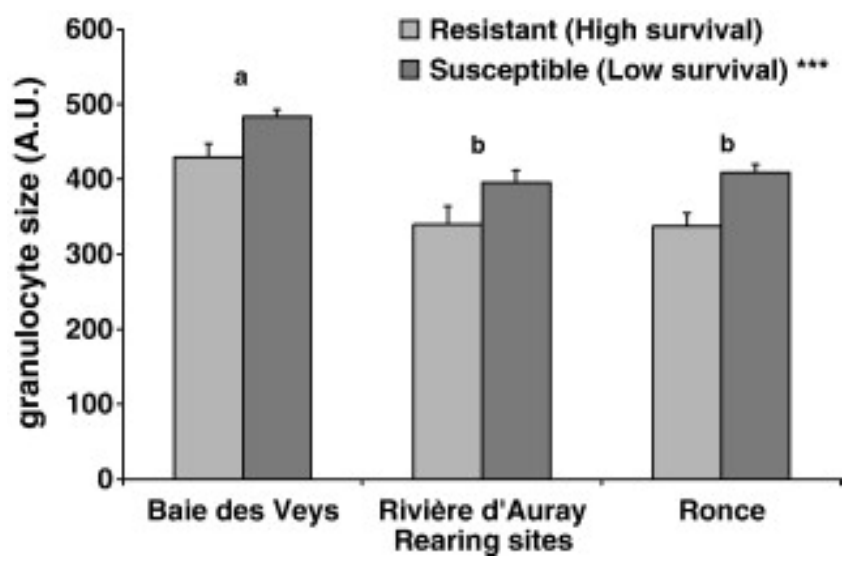

Fig. 5: Granulocyte size from resistant (High-survival) and susceptible (Low-survival) oyster families after three months rearing at three different sites: Baie des Veys, Rivière d'Auray and Ronce (Mean FSC value in arbitrary detector units $\pm S E, n=9$ ). Letters indicate significant differences between rearing sites, MANOVA, $p<0.05$; * indicates significant differences between resistant (High-survival) and susceptible (Low-survival) oyster families at $p<0.05$; ** at $p<0.01,{ }^{* \star *}$ at $p<0.001$, NS not significant. 


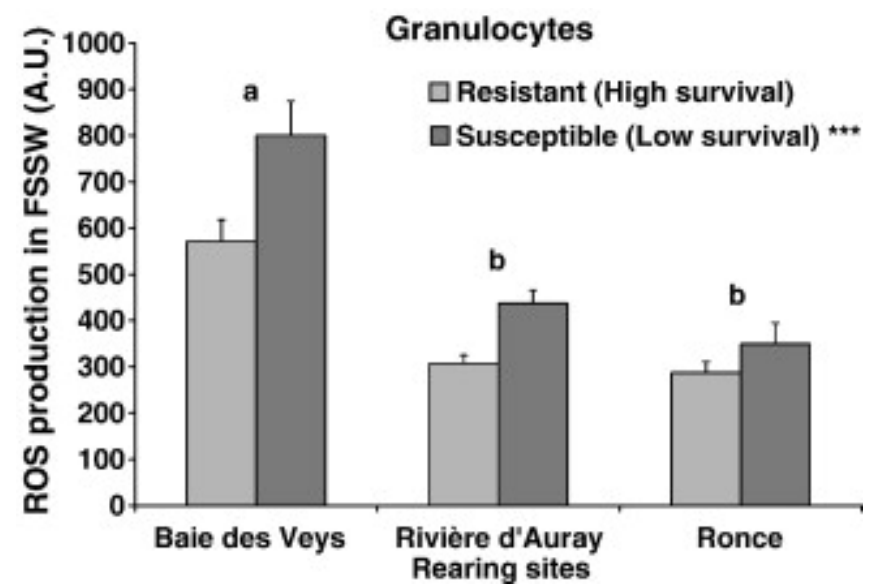

Fig. 6: Granulocyte reactive oxygen species (ROS) production of seawater-incubated hemocytes from resistant (High-survival) and susceptible (Low-survival) oyster families after three months rearing at three different sites: Baie des Veys, Rivière d'Auray and Ronce (incubation time $=$ 180 min, DCF fluorescence $=$ FL1 value in arbitrary detector units, Mean \pm SE, $n=9)$. Letters indicate significant differences between rearing sites, MANOVA, $p<0.05$; * indicates significant differences between resistant (High-survival) and susceptible (Low-survival) oyster families at $p<0.05 ; * \star$ at $p<0.01, * * *$ at $p<0.001$, NS not significant.

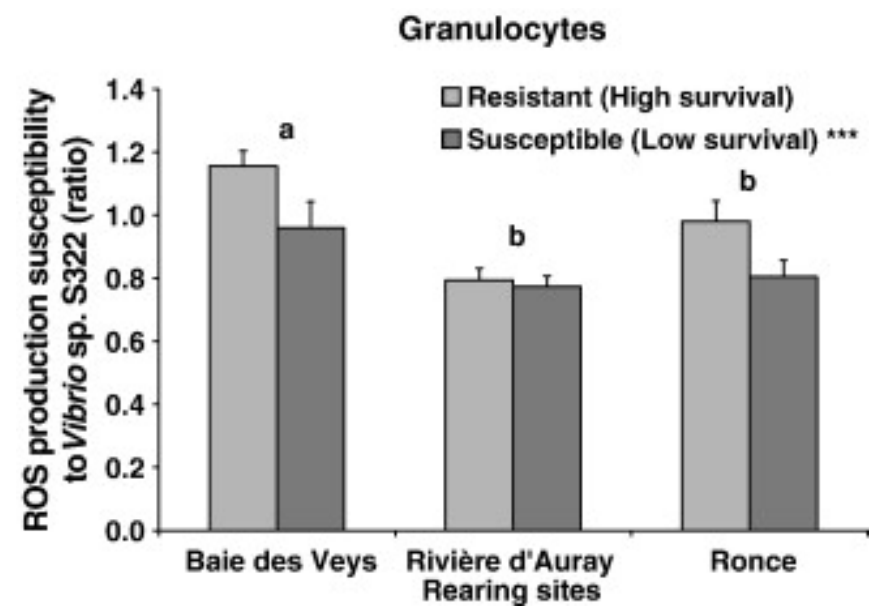

Fig. 7: Granulocyte reactive oxygen species (ROS) production by hemocytes challenged with Vibrio $\mathrm{sp}$. S322. The data are expressed as the ratio of ROS production in seawater (control) divided by the ROS production of Vibrio sp. S322-challenged hemocytes from resistant (Highsurvival) and susceptible (Low-survival) oyster families after three months rearing at three different sites: Baie des Veys, Rivière d'Auray and Ronce (Mean $\pm S E, n=9$ ). Letters indicate significant differences between rearing sites, MANOVA, $p<0.05$; * indicates significant differences between resistant (High-survival) and susceptible (Low-survival) oyster families at $p<0.05 ; * \star$ at $p<0.01, * \star \star$ at $p<0.001$, NS not significant.

Note: $A$ ratio near 1 indicates that the hemocyte ROS production is not changed by the addition of bacteria, less than 1 corresponds to an inhibition of the hemocyte ROS production and more than 1 , to an activation. 


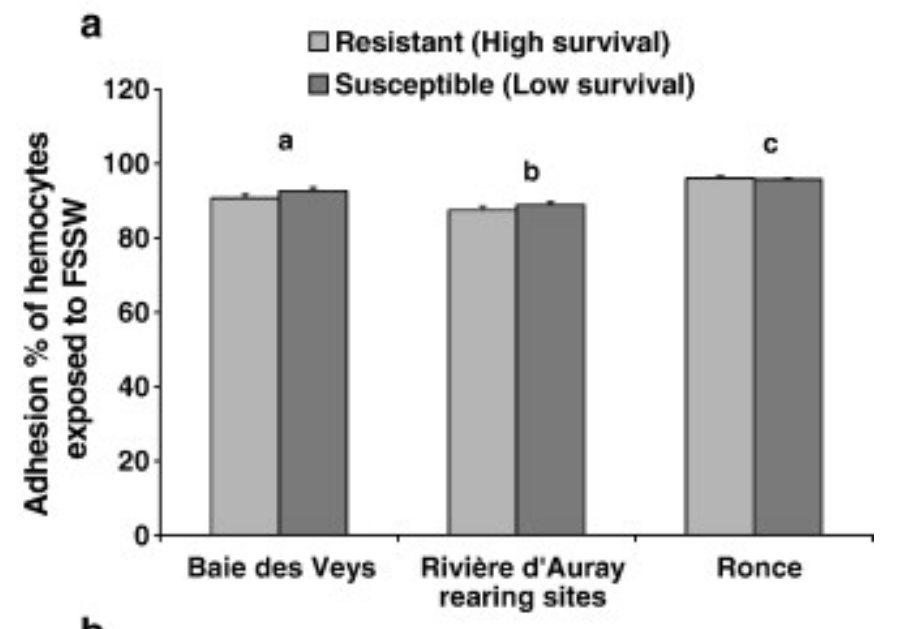

b

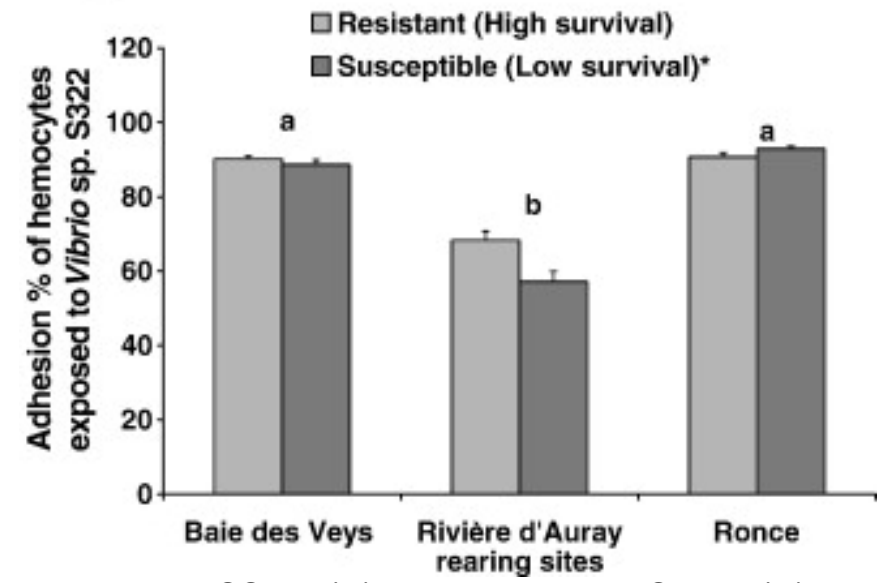

Fig. 8: Adhesion percentage in FSSW- (A) and Vibrio sp. S322- (B) exposed hemocytes from resistant (High-survival) and susceptible (Low-survival) oyster families after three months rearing at three different sites: Baie des Veys, Rivière d'Auray and Ronce (Mean $\pm S E, n=9$ ). Letters indicate significant differences between rearing sites, MANOVA, $p<0.05$; * indicates significant differences between resistant (High-survival) and susceptible (Low-survival) oyster families at $p<0.05 ;{ }^{* *}$ at $p<0.01,{ }^{* \star *}$ at $p<0.001$, NS not significant. 